\title{
Nóra Máthé
}

\section{"Are You Thor, the God of Hammers?" - Mixing the Posthuman and Old Norse Mythology in Thor: Ragnarok}

\begin{abstract}
Often considered figures of modern mythology, various superheroes are widely known and referenced due to the fact that their stories are embedded in the real world and several forms of media are saturated with their presence. These heroes and gods of the twentieth and twenty-first centuries function as archetypes. In this paper I will focus on the Marvel superhero, Thor, and his representation in the latest movie within his franchise, Thor: Ragnarok (2017). In this newest film Thor becomes an interesting representation of the posthuman condition by mixing together Norse mythology and posthumanist ideology. In my paper I will examine the relation between these two seemingly antithetical ideas.
\end{abstract}

Keywords: Posthumanism; Superhero; Thor; Mythology; Movie; Marvel.

\section{NóRA MÁTHÉ}

Babeș-Bolyai University, Cluj-Napoca, Romania mathenora@yahoo.com

DOI: $10.24193 /$ cechinox.2018.34.15 he history of Thor is as intricate as it
can be: the character originates from Old Norse mythology, but it is quite a challenge to define him due to the fact that his symbols have been used in many different instances throughout the ages. He is considered to be "a sky god, a thunder god, a god of the seas and the winds that govern them, a fertility god, a god of war and as a god who was the ultimate bulwark against monstrous evils." ${ }^{1}$ His likeness has been linked to Nazi symbolism, he was considered the enemy of Christ and today he is best known as a superhero within the American comic book series, Thor, the cartoon Mighty Thor and the movies which were inspired by the comics (Thor, Thor: The Dark World and Thor: Ragnarok). In this paper I will focus on Thor's latest big screen representation in the 2017 movie Thor: Ragnarok ${ }^{2}$ and only reference his other depictions, because Thor: Ragnarok seems to take a different approach, changing the character's overall style and mythology. First, I will give a brief description of the superhero I will be focusing on, then I will discuss his posthuman status tied together with his mythological background, 
reflecting on the above-mentioned movie and its take on Thor's persona.

Superheroes are possibly the most concrete and well-known representations of the posthuman: artificially enhanced bodies, cyborgs, futuristic equipment and superpowers are all represented in the comic book universe, and it may be argued that these heroes depict the ideal posthuman. Most heroes are good looking, muscular and an epitome of health and vitality (e.g. Superman, Wonder Woman), intelligence (e.g. Iron Man, Hulk), riches (e.g. Batman, Iron Man) or other desirable qualities (such as various superpowers) which help them become the ideal enhanced human being. Thor's backstory is different; he possesses most of these posthuman qualities in his comic book and film depictions, but he also has a mythological background which belongs to a real culture and which has its own past - and this trait is quite unique in the superhero universe. Of course, most of the above-mentioned heroes follow some kind of archetype which can be traced back to Greek or Roman mythology; some invoke parts of Egyptian myths as well, but in a more tongue-and-cheek manner, with vague references to these cultures and legends. ${ }^{3}$ Thor's mythology, however, is used as the character's backstory in its entirety, but it is also changed quite a bit in order to fit the style and tone created by previous staples such as Superman, Batman and Wonder Woman. Richard Reynolds believes that Thor's initial success is due to his artwork's creator, Richard Kirby's vision: he depicts Asgard, the land which Thor comes from, as a futuristic planet in space, not too different from other comics which showed similar worlds. ${ }^{4}$ Moreover, Thor himself is changed quite a bit from his initial depiction in the Eddas: his costume is "half traditional, half super-heroical" 5 in the comics and this is kept the same way in the movies as well: he usually wears a winged helmet and an outfit which references military gear from the Middle Ages, but he also has a red cape and his clothes showcase a lot of modern elements. His trusted weapon is Mjolnir, a hammer made of uru, a virtually indestructible metal, which also has supernatural powers. ${ }^{6}$

Because my paper focuses solely on the cinematic depiction of Thor, I will ignore the storylines showcased via the comic books and the animated series; I will only concentrate on what one can find out about the god of thunder through the current three movies. My reasoning behind this decision is the fact that although Thor has been part of the comic book universe for a long time, his character was not as easily recognizable as characters such as Superman, Spiderman or Batman, and the films have played a big part in launching this Marvel character towards mainstream success.

So, how does Thor become part of posthuman ideology? In the following segment of my paper I will discuss how posthumanism relates to superheroes and how Thor's cinematic depictions align with its ideas.

It is a troubling task to define posthumanism as one general ideology or philosophy; the term itself refers to the way thinkers try to identify the world of humans who have started to embrace technology and artificial enhancement more and more, to the point of their humanity being changed. In its simplest form, the debate lies between two camps: the ones who are wary of these changes and the ones who 
embrace technology and believe that their lives will continually get better with further scientific discoveries. Francis Fukuyama, for example, is worried about the outcome of such drastic changes of human nature. His question is what "will happen to political rights once we are able to, in effect, breed some people with saddles on their backs, and others with boots and spurs?" The debate focuses on questions of morality and even mortality, but it also represents a clash of two ideas. As Bart Simon puts it, in the above-mentioned quote, Fukuyama, like many other philosophers, puts up a "staunch defense of the state regulation of biotechnology grounded in an Enlightenment narrative of a shared and inviolable human essence." 8 The posthuman future mentioned by Fukuyama is arguably introduced by transhumanism, this being considered the transition period between humanism and posthumanism. The difference between post- and transhumanism is that transhumanism is a "more or less coherent set of techno-optimist ideas, whereas by contrast posthumanism is suggested to stand as a 'highly ambiguous notion' at best demarcated by its principle break with humanism." Scott Jeffery points out that the way this debate is viewed is quite skewed because it ignores a very important chunk of discourse about the topic: "Just as visions of posthumanity have emerged in a techno-scientific discourse of Transhumanism and the critical-philosophical discourse of Post/Humanism, the history of science fiction displays a similar concern with the question of what it means to be human, and what comes after the human." ${ }^{10}$ Furthermore, Jeffery argues that, although this might not be considered an important part of the discussion on posthumanism, comic books and science fiction have been acutely aware of the same questions and issues, but they have used different methods and means of communication to discuss them. ${ }^{11}$ With these methods a wider audience has become at least more aware of some possibilities: through the self-reflections of Superman on how dangerous he is to humanity or by showing the destruction left behind after a battle the Avengers fought against bad guys. These story elements may not go into an in-depth analysis of the posthuman future, but they certainly reflect on the very issues which philosophers bring up. The newest cinematic depiction of Thor in the movie Thor: Ragnarok certainly provides a place for discussions about how humanity is changing and even on how to deal with these changes.

It is important to stress the fact that Thor: Ragnarok represents quite the change in the franchise's representation. The first movie, Thor (2011) ${ }^{12}$ establishes the character's history and ties it into the human world's myths: planet Earth is one of the nine realms of Asgard, the planet where Thor comes from. Thus, Old Norse mythology is changed to fit the Marvel universe, but it still resembles the original mythological concept. According to Old Norse mythology, Asgard, the abode of gods, is similar to Olympus in concept, it is the place where the gods live, somewhere in the skies, but it is also an enclosure because it has walls to keep the gods secure and Thor is the known protector of this land. ${ }^{13}$ The movie also references the $\mathrm{Bi}$ frost or Bilröst, which is a bridge between heaven, Asgard and the human world, Midgard. ${ }^{14}$ Thor captures these general ideas, but it makes them much more futuristic: Thor himself is considered an alien 
of some sort on planet Earth, and he even references the Hubble telescope to scientifically prove his world's existence to Jane, the human scientist. ${ }^{15}$ Although the second movie, Thor: The Dark World (2013) has a different director, it keeps to the vision of the first film and respects its mythological background fairly well. These two movies are similar in style to movies depicting the legends of Olympus, with the added comic relief of Thor being an alien in the modern human world, thus unable to use human technology, which has never been part of mythologies. Heroes and gods are usually represented as beings similar to humans, but stronger and more developed. Both movies capture this mythological trope and keep Thor's character more serious than other Marvel heroes, even though they do add elements of comedy when he leaves Asgard. Thor: Ragnarok, on the other hand, distances itself from this mythological background in many instances of the movie, bringing Thor's character from its mythological past closer and closer to the "traditionally" posthuman Marvel heroes. Richard Lawson points out that the latest Thor-movie is more similar in tone to the Guardians of the Galaxy franchise and less to the mythological, more serious world of the god of thunder: "But the problem is that this is a Thor movie, and a direct part of the Avengers continuity-so Waititi must eventually pull his attention away from all this play and do his mythology homework." ${ }^{17}$ Although Thor: Ragnarok received praise from critics and has been named the funniest Marvel movie yet, ${ }^{18}$ it certainly changed the character's perception as well. So, how did Thor's story become a representation of debates around posthumanism?
The third installment in the series starts off with the grim prediction that Asgard will undergo Ragnarok, "the end of everything," ${ }^{19}$ a sort of apocalypse which will force its inhabitants to make changes in everything that they know. Thor's first approach to solve this problem is a rather humanistic one: he values Asgard as his people's vessel, home to their culture and knowledge, and his initial idea is to try and save his homeworld from destruction. To achieve this, he puts together a team and tries to defeat Hela, the goddess of death, but the movie's ending brings a surprising outcome: the team of heroes cannot stop the destruction of Asgard and instead they evacuate, leading the Asgardians onto a large spaceship. To further analyze this outcome, we need to back up a little and look at the characters' and their plotlines in more depth.

In the first movie Thor explains that in his world science and magic are closely intertwined and they refer to generally the same thing ${ }^{20}$ which is showcased through the blurring of these terms: the Asgardians use a beam called the Bifrost to teleport into the human world; their world is a mixture of futuristic and classical design; their social and political status resembles the one humans used during the reign of monarchs (the king, Odin rules over the nine realms, blood relations matter, the king lives in a castle, wears a crown, has to name his successor, etc.). Although this is not changed in Thor: Ragnarok and Thor actually becomes king in the end, it is definitely altered to fit a more futuristic and a less mythological ideology. One might argue that these changes have been made in order to make Thor more relatable and better understood, but his only new trait 
that points to this is his humor, which was not developed in the earlier movies. $\mathrm{Hu}-$ man beings do not necessarily relate better to science fiction than mythological fiction, although there is an argument to be made about the genre's popularity in the 2010s: with the continuation of franchises such as Star Wars and Star Trek, the undeniable success of Guardians of the Galaxy and most superheroes' direct connection to space and aliens (e.g. Superman himself is from a different planet), it certainly seems marketable to make Thor: Ragnarok a space adventure filled with spaceships and large lasers. However, this does not take away from the argument at hand. As Jeffery explains:

Superhero comics may not be an accurate guide to Transhumanist technologies, nor do they fully embrace the Post/Humanist interrogation of the tenets of humanism. Nevertheless, when considering the promises and pitfalls that await us, and our bodies, in the posthuman future, we could do worse than the ethical template of the Superhuman, which thrives on teams consisting of alien, robot, cyborg, mutant, and human bodies working together, and which recognizes the human as a verb and not a noun and whose every existence is premised on becoming rather than being. ${ }^{21}$

Thor: Ragnarok works exactly this way. The film suggests that in order for Thor to stay strong and conquer his enemies, he needs to embrace what it is like to be a posthuman. He needs to be able to pilot spaceships and he needs to have a mobile phone. He is forced to use these technologies when he is cast on the planet of Sakaar. This need for change is signified both visually and symbolically in the movie: Hela, the goddess of death destroys Mjolnir, Thor's supposedly indestructible hammer, thus leaving him without his mythological weapon. Once he crashlands on Sakaar, his long blonde locks are also cut off, thus his traditional look is changed. His new hairdo brings him out of the mythological past and gives him a more modern look, and, by the end of the movie, his costume undergoes some changes as well, making his overall image align more with the rest of the Avengers' clothing.

Furthermore, Thor's new team of heroes includes Valkyrie, the last living member of the legendary Valkyrior, a group of female warriors. ${ }^{22}$ The movie introduces her as Scrapper 142, who catches Thor and takes him to the leader of Sakaar. Her identity as an elite Asgardian warrior is only revealed later on, until then she fits in as a citizen of this strange planet. She keeps her identity secret and hides on Sakaar because her Valkyrie sisters were all killed in battle by Hela the first time she escaped, and so, she learns the ways of this new world and becomes an expert pilot and shooter. The change is massive: the Valkyrior traditionally ride winged horses and fight with swords and other such weapons.

Another one of Thor's helpers is Bruce Banner, the Hulk, a combination of brute strength and a great scientific mind, who is also capable of operating a spaceship. Thor himself realizes that he does not necessarily need his hammer to use his powers, his father even asks him "Are you Thor, the god of hammers?,"23 but until this discovery he is forced to improvise and to use tools offered by the futuristic world of Sakaar, 
which operates very differently compared to Asgard. In Thor the god of thunder is seen riding a horse on the rainbow bridge and he searches for a horse as a means of travel when he is on Earth as well. That, however, is completely omitted in Thor: Ragnarok. There is no need for a simple horse to move around when he can use his powers of flight, thunder and technology.

Thor: Ragnarok does not offer a clear commentary on the posthuman condition and it does not claim to do so. However, it offers questions and possible solutions just the way critics or embracers of the posthuman condition do so. It reflects on what may happen when inevitably a species loses its home planet and is forced to change its living completely, leaving behind everything its members have ever known. It also showcases the fears Fukuyama mentioned in Our Posthuman Future: Grandmaster, the ruler of Sakaar, uses the planet as his plaything, he captures and enslaves lesser life forms and uses them as his champions in a fight to the death against one another, reducing them to nothing but his objects. This depiction invokes questions of the posthuman condition and morality, but also questions raised by postcolonialism.

Thor, one of the very last superheroes embedded in a different culture, other than the ones perpetually using science to get and use their powers, has gone through a complete change: although Thor: Ragnarok showcases many questions and concerns about our posthuman future, it also seems to suggest that Thor has to pick up speed and learn the ways of his transhuman present in order to be able to stay a hero. Jeffery suggests that "posthuman bodies are enmeshed in social, technological and discursive systems. In this sense human bodies are always already posthuman bodies; there are no human beings, only human becomings." ${ }^{24}$ Thor, certainly matches this description of the posthuman body: he is undergoing this "becoming" in front of our very eyes, embracing some of what posthumanism has to offer and questioning other aspects, and leaving some of his human and mythological past behind.

\section{Works Cited}

Abad-Santos, Alex, "Thor: Ragnarok Finally Makes Thor a Hero Worth Rooting For," Vox, November 2, 2017, online: https://www.vox.com/culture/2017/10/26/16537186/thor-ragnarok-review (accessed December 30, 2017)

Arnold, Martin, Thor: Myth to Marvel, London \& New York, Continuum International Publishing Group, 2011

Fukuyama, Francis, Our Posthuman Future: Consequences of the Biotechnology Revolution, New York, Farrar, Straus and Giroux, 2002

Jeffery, Scott, The Posthuman Body in Superhero Comics, Palgrave Macmillan, e-Book, 2016

Lawson, Richard, “Thor: Ragnarok Review: Taika Waititi Almost Transcends the Marvel-Verse,” Vanity Fair, October 25, 2017, online: https:/www.vanityfair.com/hollywood/2017/10/thor-ragnarok-review-marvel-chris-hemsworth-taika-waititi (accessed December 28,2017)

Lindow, John, Norse Mythology: A Guide to the Gods, Heroes, Rituals and Beliefs, New York, Oxford University Press, 2001

MacFarlane, James Michael, “Boundary Work: Post- and Transhumanism, Part I," Social Epistemology Review and Reply Collective, vol. 4, no. 1, 2014

Reynolds, Richard, Super Heroes - A Modern Mythology, Jackson, University of Mississippi Press, 1992 Rovin, Jeff, The Encyclopedia of Superheroes, New York, Facts and Files Publications, 1985 
Simon, Bart, "Introduction: Towards a Critique of Posthuman Futures," Cultural Critique, no. 53, "Posthumanism,"Winter 2003

Thor, directed by Kenneth Branagh, prod. Marvel Studios, distributed by Paramount Pictures, 2011

Thor: Ragnarok, directed by Taika Waititi, prod. Marvel Studios, distributed by Walt Disney Studios Motion Pictures, 2017

Thor: The Dark World, directed by Alan Taylor, prod. Marvel Studios, distributed by Walt Disney Studios Motion Pictures, 2013

\section{Notes}

1. Martin Arnold, Thor: Myth to Marvel, London \& New York, Continuum International Publishing Group, 2011, p. IX.

2. Thor: Ragnarok, directed by Taika Waititi, prod. Marvel Studios, distributed by Walt Disney Studios Motion Pictures, 2017.

3. Richard Reynolds, Super Heroes - A Modern Mythology, Jackson, University of Mississippi Press, 1992, p. 53.

4. Richard Reynolds, op. cit., p. 54.

5. Ibidem.

6. Jeff Rovin, The Encyclopedia of Superheroes, New York, Facts and Files Publications, 1985, p. 310.

7. Francis Fukuyama, Our Posthuman Future: Consequences of the Biotechnology Revolution, New York, Farrar, Straus and Giroux, 2002, pp. 9-10.

8. Bart Simon, "Introduction: Towards a Critique of Posthuman Futures," Cultural Critique, no. 53, "Posthumanism,"Winter 2003, p. 1.

9. James Michael MacFarlane, "Boundary Work: Post- and Transhumanism, Part I," Social Epistemology Review and Reply Collective, vol. 4, no. 1, 2014, p. 52. He offers quotes from Post- and Transhumanism: An Introduction, ed. Robert Ranisch and Stefan Lorenz Sorgner.

10. Scott Jeffery, The Posthuman Body in Superhero Comics, Palgrave Macmillan, e-Book, 2016, p. 12.

11. Ibidem, pp. 12-14.

12. Thor, directed by Kenneth Branagh, prod. Marvel Studios, distributed by Paramount Pictures, 2011. 13. John Lindow, Norse Mythology: A Guide to the Gods, Heroes, Rituals and Beliefs, New York, Oxford University Press, 2001, pp. 61-62.

14. Ibidem, pp. 80-81.

15. Thor, op. cit.

16. Thor: The Dark World, directed by Alan Taylor, prod. Marvel Studios, distributed by Walt Disney Studios Motion Pictures, 2013.

17. Richard Lawson, "Thor: Ragnarok Review: Taika Waititi Almost Transcends the Marvel-Verse," Vanity Fair, October 25, 2017, online: https://www.vanityfair.com/hollywood/2017/10/thor-ragnarokreview-marvel-chris-hemsworth-taika-waititi (accessed December 28, 2017).

18. Alex Abad-Santos, "Thor: Ragnarok Finally Makes Thor a Hero Worth Rooting For," Vox, November 2, 2017, online: https://www.vox.com/culture/2017/10/26/16537186/thor-ragnarok-review (accessed December 30, 2017).

19. Thor: Ragnarok, op. cit.

20. Thor, op. cit.

21. Scott Jeffery, op. cit., pp. 236-37.

22. Jon Lindow, op. cit., pp. 95-97.

23. Thor: Ragnarok, op. cit.

24. Scott Jeffery, op. cit., p. 236. 